\title{
TANITMA 2 / BOOK REVIEW 2: Şahiner, Mustafa (2016). Yüce Türk'ten Zalim Türk'e: Erken Modern Dönemi İngiltere'sinde Türk Algrsı. Ankara: Siyasal Kitabevi, 1. bask1, 144 sayfa, ISBN: 978-605-9221-22-1
}

Volkan KILIÇ`1

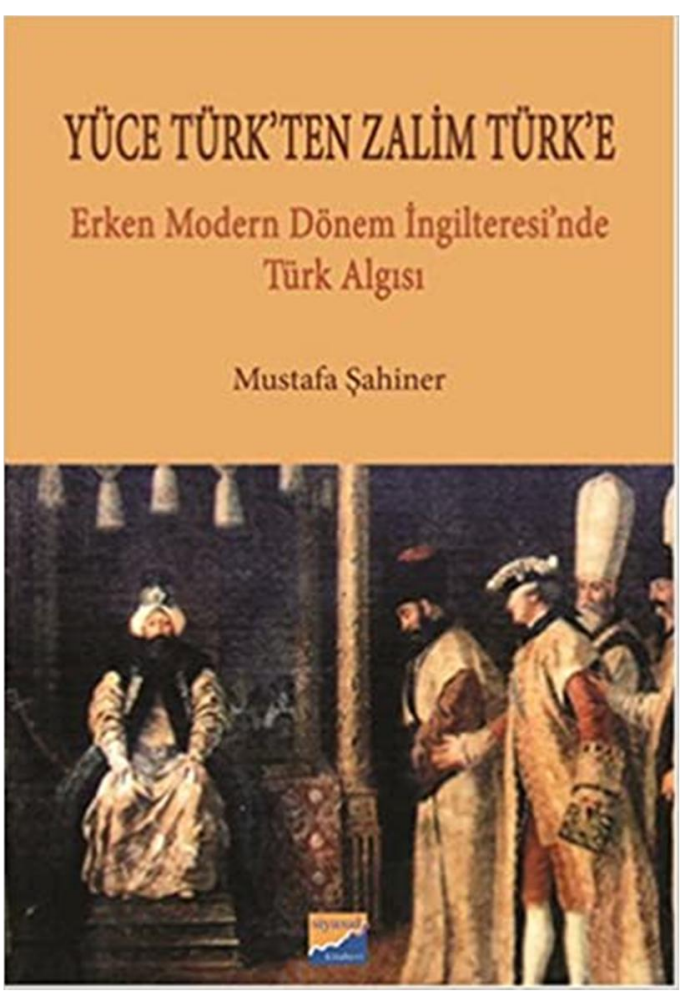

düzeyde kırmamış gibi görünmektedir.
Mustafa Şahiner tarafından yazllan, Yüce Türk'ten Zalim Türk'e: Erken Modern Dönemi İngiltere'sinde Türk Algısı adlı kitapta, kökenleri Ortaçağa kadar giden Türk-İngiliz münasebetlerine tarihsel ve yazınsal açıdan yaklaşılarak, özellikle İngilizler tarafından Türklere özel bir ilginin olduğu erken dönem İngiltere'sinde yazılan tiyatro oyunlarında, düzyazı eserlerinde, kilise vaazlarında ve diplomatik belgelerde bahsedilen Türk temsili üzerinde durulmaktadır. Erken dönem İngiltere'sinde, ekonomik ve politik olarak özellikle Avrupa dışındaki milletlerle ve devletlerle ikili ilişkiler oldukça ilerlemiş, bu ekonomik ve diplomatik ilişkiler dönemin edebiyat eserlerine de dikkat çekici ölçüde yansımıştır. $\mathrm{Bu}$ bağlamda, erken dönem İngiliz tiyatrosunda Türk temsili özellikle oldukça popüler hale gelmiştir. Türklerin İngiliz tiyatrosunda temsili her ne kadar sorunlu ve negatif eksende olsa da, özellikle Kraliçe I. Elizabeth döneminde Türklerle çok yakın, yapıcı ve sıcak ilişkiler kurulmuş; bu olumlu ve sıcak diplomasi trafiği İngiliz tiyatrosuna da Türklere karşı çoğu zaman olumsuz olan önyargıyı beklenebilecek

Bu kitapta erken dönem İngiltere'sinde Türk-İngiliz münasebetleri çerçevesinde yazılmış olan resmi yazılar, mektuplar, kilise hutbeleri, kilisede verilen vaazlar, sokak balatları ve tiyatro metinleri detaylı bir şekilde irdelenerek özellikle Saray tarafından yapılan diplomatik yazışmalarda oldukça fazla sayıda geçen "Yüce Türk" imajının, o dönemki İngiliz toplumunda çok da olumlu bir yer bulamadığı ve o dönemde üretilen gerek yazınsal gerek de dinsel metinlerde daha ziyade "Zalim Türk" imajının ön planda olduğu öne sürülmektedir. Bu çerçevede, o dönemde yazılmış olan İngiliz hutbelerinde, sokak balatlarında ve İngiliz tiyatrosunda Türkler, çoğunlukla Müslüman kimliklerinden dolayl, "kâfir", "putperest", "şeytan” "İsa-karşıtı", "kana susamış", "zalim”, ve "hilekar" gibi bir takım olumsuz tanımlamalara maruz bırakılmış ve bu şekilde çoğu yazınsal türlerde olumsuz bir çerçevede temsil edilmişlerdir.

Kitapta, Türk-İngiliz ilişkilerinde çoğu zaman resmi anlamda yaratılan olumlu diplomatik ilişkilerin, özellikle I. Elizabeth ve I. James dönemlerinde İngiltere ve Osmanlı ile karşılıklı ekonomik ve politik işbirliğinin, popüler kültüre ve halk kültürüne bu derece olumlu yansımadığı ve Türklere karşı dini duygulardan ötürü süregelen "kafir" ve "zalim” tanımlamalarının İngiliz toplumunda oldukça yaygın

$1 \quad$ Dr. Öğr. Üyesi, Hatay Mustafa Kemal Üniversitesi, Fen Edebiyat Fakültesi, Batı Dilleri ve Edebiyatları Bölümü, İngiliz Dili ve Edebiyatı ABD (Hatay, Türkiye), volkankilic25@hotmail.com, ORCID ID: oooo-ooo1-8961-5519 [Makale kayıt tarihi: 12.05.2020-kabul tarihi: 20.06.220; DOI: 10.29000/rumelide.753347] 
bir şekilde dile getirildiği ve kullanıldığı belirtilmekledir. Özellikle Türkler hakkında, Osmanlı İmparatorluğunun üç kıtada hüküm sürmesinin yanı sıra, politik ve ekonomik gücü elinde bulundurması sebebiyle, Batı'da daha çok “emperyal kıskançlık" ve fethedilme korkusu içerinde bir psikolojiyle karşılanmış ve Türklere yönelik bu olumsuz etiketler batı yazınında oldukça geniş yer bulmuştur.

Kitabın ilk bölümünde Türk-İngiliz ilişkilerinin tarihsel arka planı ve gelişimi üzerinde durulmaktadır. Buna göre, tarihte ilk Türk-İngiliz münasebetleri, Haçlı seferlerinde 1097 yılında Normandiyalı William'ın Anadolu'ya kadar gelmesiyle beraber Ortaçă̆'ın başlangıcına kadar gitmektedir. O dönemde Anadolu'da Büyük Selçuklu İmparatorluğu egemenliği sürmekteyken, Avrupa ile ilişkileri de yok denecek kadar az olması sebebiyle, Türk imgesi daha çok doğulu Müslüman kimliğiyle tanınmaktaydı. Fakat Osmanlı devletinin on üçüncü ve on dördüncü yüzylllarda kurulup gelişmesi ve Avrupa'ya açılması ile beraber, Türklerle İngilizler birçok kez savaş alanlarında karşılaşmış olmakla beraber sürdürülen resmi ilişkiler çatışma ve savaş ortamından dolayı oldukça olumsuz bir hâl almıştı. Şahiner'e göre, barışçıl ortamda ilk resmi ilişkilerin başlaması ise on altıncı yüz yıla rastlamaktadır (2016: 9). Erken modern döneme rastlayan bu ikili ilişkiler, daha çok Osmanlı İmparatorluğunun Akdeniz e Avrasya'ya hâkim olması ve dolayısıyla İngiltere'nin ekonomik çıkarları açısından oldukça önemli olması sebebiyle iyi seyretmiştir.

Erken modern dönemde Türklerin ekonomik ve politik güç bakımından doruk noktası olması münasebetiyle, Protestan mezhebini benimseyen İngilizler, Katolik İspanyol tehlikesine karşın Osmanlı Devleti ile çok iyi ilişkiler içerisine girdiğini görmekteyiz. Resmi düzeydeki Türk-İngiliz ilişkileri de tarihten bu yana sürdürülen olumsuz Türk algısını bir nebze olsun kırarak, erken dönem İngiltere'sinde Türklerin daha çok olumlu temsil edilmesi o dönemdeki gerek diplomatik belgelere gerekse edebiyat eserlerine yansımaktadır. Bu doğrultuda, erken dönem İngiltere'si, Katoliklikten ayrılarak, Protestanlığı benimsemesi ve Roma Katolik Kilisesiyle tüm bağlarını kopararak kendi Anglikan Kilisesini kurmasıyla beraber, Katolik olan Venedik, Fransa ve İspanya tarafından dışlanmış ve Avrupa arenasında ticaret ve ekonomik anlamda yalnızlaştırılmıştı. Bundan dolayı İngiltere bu dönemde Osmanlı ile ittifak kurarak, ticaret ve diplomasi alanında Akdeniz'de olma ve Pazar arayışını Osmanlı ile geliştirmeyi amaçlamıştır. Öte yandan, İngiltere Osmanlı’nın sadece ekonomik değil, Katolik Fransa ve İspanya tehlikesine karşın askeri desteğine de ihtiyaç duymaktaydı. Bu doğrultuda, Osmanlı ile iyi ilişkiler kurmak o dönem İngiltere'si için oldukça ehemmiyet arz etmekteydi çünkü "Osmanlı toprakları büyük bir pazardı ve İngilizler o pazardan pay almak için can atmaktaydı" (Şahiner, 2016: 17).

Tarihsel perspektiften bakıldığında, Osmanlı-İngiliz münasebetleri 1570 'lerde başlamaktadır. Bu dönemde İngiltere, Joseph Clements ve John Wight adlı iki İngiliz tüccarı Osmanlı ile ticari ilişkilerin resmi olarak başlatılması dolayısıyla İstanbul'a gönderdi. Bu suretle İngiliz tüccarlar Osmanlı topraklarında serbest dolaşım hakkı kazandılar. Fakat, Osmanlı topraklarında ticaret yapan Venedik ve Fransa'nın bu durumdan oldukça rahatsızlık duymaları ve engellemeye çalışmaları, İngiltere'yi diplomatik anlamda daha çok harekete geçirerek, ikili iyi ilişkilerin başlaması ve devam etmesi anlamında bizzat I. Elizabeth'in aynı zamanda iyi bir casus da olan William Harborne'u, Sultan Üçüncü Murat'a yapılan bir diplomatik mektupla İstanbul'a göndermesiyle Türklerle İngilizler arasında ilk resmi diplomatik ilişki de başlamış oldu. Bu dönemde yapılan diplomatik yazışmaların Osmanl-İngiliz ilişkilerinde olumlu bir yönelimi de işaret etmektedir. Kraliçe Elizabeth, Türklerin sempatisini kazanarak, 1580 tarihinde Osmanlının İngiliz tüccarlara ayrıcalıklar tanımasını sağlayan bir imtiyazname imzalamasıyla iki ülke arasında serbest ticaretin de başlamasına yön vermiştir. Diğer 
yandan, Osmanlı ile ikili ilişkilerin kurulması İngiltere açısında askeri ve politik bir öneme de sahipti. Osmanlı ile Katoliklere karşı bir ittifak İngiltere için son derece önemliydi. Bu yüzden Kraliçe Elizabeth, Osmanlı'ya gönderdiği mektuplarda sürekli olarak Katolik ve Protestan mezhepler arasındaki farklara ve Protestanlık ve Islam dini arasındaki benzerliklere dikkat çekmekteydi. Hatta yazdığı bir mektupta Kraliçe Elizabeth "Isa'nın koyduğu kaideleri yozlaştıran putperestlere karşı [Katolikler] hakiki dinin mağlub olmaz kudretli hamisi” diyerek Sultan Üçüncü Murad'a hitap etmektedir (Şahiner, 2016: 36).

Sonuç olarak, kitapta bahsedilen erken dönem Türk-İngiliz münasebetlerinin ticari ve askeri işbirliğinden öteye gitmediği, bu bağlamda, İngiltere'nin İstanbul'da diplomatik temsilci bulundurmasına rağmen Türkleri kültürel ve sosyolojik olarak anlamaya çalışmaması ve Türklerin kültürel zenginliklerinden hiç bahsetmemesi bu dönemki Türk-İngiliz münasebetlerinin erken dönem İngiltere'sinde sokak kültüründe ve popüler kültüre olumlu yansımamasına da sebebiyet vermektedir. Böylelikle, İngiliz yazını ve popüler kültürde bahsedilen Türk imgesi, daha çok, ortaçağdan bu yana var olan önyargılara, yani Türklerin "barbar" ve "kafir" olmasına, dayanmaktadır.

Kitabın ikinci bölümünde erken modern dönem İngiliz hutbelerinde ve kilise vaazlarında temsil edilen Türk imajı irdelenmektedir. Bu bağlamda, kitapta yazar tarafından şu kanıya varılmaktadır: Kraliçe Elizabeth ve Üçüncü Murad devri Osmanl-İngiliz diplomatik yazışmalarında her ne kadar siyasal ilişkilerde ortaya çıkan olumlu denebilecek "Yüce Türk" imgesine yer verilmekte ise de, aynı dönemde İngiltere'de kilise vaazlarında, hutbelerde ve din adamları tarafından yapılan dualarda "kötü Türk" imgesi yaygın olarak görülmekteydi. Bu şekilde, denilebilir ki Protestan İngiliz kilisesi siyasal yapıdan ve oluşumdan ayrı hareket ederek, dini söylemlerde her defasında Türklerin barbar, kafir ve zorba olduğu yer almaktadır. Kiliselerin olumsuz bakış açısı her ne kadar tarihsel İslam ve Türk düşmanlığına dayansa da aslında erken dönem Avrupa'sında çok sayıda Hristiyanın ve İngiltere'de çok sayıda Protestanın din değiştirip Müslüman olmasından kaynaklanmaktadır. Bu açıdan Şahiner bu tezini çok sayıda vaaz, hutbe ve kilise yazılarından almaktadır.

Kitabın üçüncü bölümünde, erken dönem İngiltere'si sokak balatlarında Türk imajı üzerinde durulmaktadır. Aynı şekilde, kilise yazılarında, vaazlarda ve kilise hutbelerinde Türklerle ilgili oluşmuş olan olumsuz söylemler ve imajlar, erken dönem İngiltere'sinde yazılmış olan sokak balatlarında da Türkler ve Müslümanlar kana susamış canavar ve korkak olarak betimlenmektedir. Diğer bir taraftan, sokak balatlarının ve kilise vaazlarının popülerlikleri vasıtasıyla çok sayıda insana ulaşmış olması münasebetiyle, kitapta da vurgulandığı gibi, İngiliz toplumunun genelinde olumsuz bir Türk algısı oluşturulmuş ve bu olumsuz hava dönemin edebiyat eserlerine de sıklıkla sirayet etmiştir.

Kitabın dördüncü bölümünde modern erken dönem İngiliz tiyatrosunda Türk tasvirleri incelenmiştir. Şahiner'e göre, erken dönemde batıda çok hızlı bir şekilde Osmanlıya karşı alakanın olması dolayısıyla, özellikle İngiltere'de, Türklerle ilgili yayımlanmış yaklaşık olarak 3176 adet esere rastlanmaktadır (Şahiner, 2016: 100). Türklere karşı duyulan bu ilgiden dolayı, İngiltere'de 1580 ile 1642 yılları arasında Türkleri konu edinen yaklaşık 47 tiyatro eseri yazılmış, fakat o dönem İngiltere'sinde kilise vaazları, hutbeler ve sokak balatlarının aksine tiyatro eserlerinde Türkler her ne kadar olumsuz olarak çizilmişse de olumlu tiplemelere de yer verilmektedir. Kitapta bu şekilde tasvir edilen dönemin İngiltere'sinde yazılmış olan tiyatro eserlerinden, anonim olarak yazılan Solymannidae (1582) ve Philip Massinger tarafından yazılan The Renegado (1624) eserleri de örnekleme teşkil etmesi manasıyla incelenmektedir. Bu şekilde, her iki tiyatro eserinde de yansitıldığı üzere, erken dönem İngiltere'sinde yazılan tiyatro eserlerinde Türkler zalim, kafir, şehvet düşkünü, barbar ve Hristiyan 
düşmanı olarak temsil edilmektedir. Şahiner'e göre, İngiliz tiyatrosunda erken dönemde sahnelenen ve yazılan bu olumsuz imaj yansımaları, batıda ortaya çıkan oryantalist söylemlere, Türkleri ve İslamiyet'i ötekileştirme konusunda oldukça katkıda bulunmaktadır.

Daha önce İngiliz edebiyatında Türk temsili ile ilgili çok sayıda araştırma yapılmış ve birçok kitap yazılmıştır. Fakat bu araştırmaların çoğu daha çok yabancı yazarlar tarafından İngilizce olarak yayımlanmış olması dolayısıyla Şahiner 'in bu kitabı Türk okurlar için hem erken dönem İngiltere'si Türk-İngiliz ilişkileri bağlamında diplomatik ilişkilerini daha iyi algılamalarında hem de Türklerle ilgili yazılan tiyatro eserlerinin anlaşılması konusunda fayda sağlamaktadır. Özellikle kitabın Türk-İngiliz ya da Osmanlı-İngiliz ilişkilerini tarihsel açıdan ele alarak, o dönemde yazılan çok sayıda diplomatik belgeleri, mektupları, kilise yazılarını ve hutbeleri de irdelemesi ve örneklendirmesi hususunda alana bir katkı sunmaktadır. 